\title{
Seed Rate Effects on Rainfed and Irrigated Safflower Yield in Eastern Mediterranean
}

\author{
S.K. Yau ${ }^{*}$ \\ Faculty of Agricultural and Food Sciences, American University of Beirut, Beirut, Lebanon
}

\begin{abstract}
Effects of seed rates on grain, straw and oil yield of safflower (Carthamus tinctorius L.) were studied for two years in the semi-arid central Bekaa Valley of Lebanon. Three trials, two under rainfed and one under supplementary irrigations, were conducted using seed rates of $6,12,24$ and $48 \mathrm{~kg} \mathrm{ha}^{-1}$ corresponding to intra-row spacing of 20, 10, 5, and $2.5 \mathrm{~cm}$, respectively. There was significant seed-rate by trial interaction on grain, straw and oil yield. In general, significant seed rate effects did not exist in the rainfed trials in 2004 and 2005, confirming that safflower has the capacity to compensate for planting density. In the irrigated trial in 2005, the 24 and $48 \mathrm{~kg} \mathrm{ha}^{-1}$ seed rates gave higher grain, straw and oil yields than the lower seed rates. Averaged over trials, the $24 \mathrm{~kg} \mathrm{ha}^{-1}$ seed rate gave the highest yields. Even if supplementary irrigation is not available, the large variation in annual rainfall in semi-arid areas warrants the use of $24 \mathrm{~kg}$ $\mathrm{ha}^{-1}$ seed rate as it will benefit in years with above-average rainfall.
\end{abstract}

Keywords: Intra-row spacing, seed-rate by trial interaction, semi-arid areas, Bekaa Valley of Lebanon, safflower cropping system.

\section{INTRODUCTION}

Safflower (Carthamus tinctorius L.) has been grown for centuries. It was first cultivated for its colorful petals which were used as a food coloring and flavoring agent, and for preparing textile dyes in Asia and the European Caucasus [1]. However, for the last fifty years, this crop was primarily cultivated for production of high-quality vegetable oil in semiarid regions of Asia, Australia, Americas and Europe. The importance of vegetable oil crops has increased over the years following a higher consumer demand for healthier edible oils. In West Asia and North Africa in general and Lebanon in particular, consumer demand for vegetable oil has been fulfilled by import, as local production of vegetable oils other than olive oil is minimal. Farmers in the region need to be encouraged to grow oilseed crops, such as safflower, to meet local consumer demand.

Safflower, which originated in eastern Mediterranean, is adapted to relatively low rainfall areas receiving winter and spring rainfall with a dry atmosphere during flowering and maturation [2]. It is a drought tolerant crop, because it has long roots that can take up water deep down in the soil profile. Earlier studies in Cyprus showed that oil seed crops, including safflower, can be successfully grown in high rainfall areas or in low rainfall areas with supplemental irrigation [3]. Recently, it was showed that safflower can be grown successfully and economically in a semi-arid Mediterranean environment [4].

Seed rate is one of many agronomic practices that can affect yield and quality of our crops. Although safflower is an under-utilized crop in the world, some research on its optimal seed rate has been conducted. In sole cropping in

*Address correspondence to this author at the Faculty of Agricultural and Food Sciences, American University of Beirut, Beirut, Lebanon;

E-mail: sy00@aub.edu.lb
India, Pakistan and neighboring countries, a seed rate of 18$22 \mathrm{~kg} \mathrm{ha}^{-1}$ is common [1]. Studies in California, USA indicated that grain yield was greatest with seed rates of 23$35 \mathrm{~kg} \mathrm{ha}^{-1}$ [5]. A seed rate of $20 \mathrm{~kg} \mathrm{ha}^{-1}$ was found to be optimal in the Washington State of USA [6], but $32-40 \mathrm{~kg}$ $\mathrm{ha}^{-1}$ was required to obtain maximum grain yields in Alberta, Canada [7]. In the Wimmera region of Victoria, Australia, higher yield was obtained with a seed rate of $17 \mathrm{~kg} \mathrm{ha}^{-1}$ or higher [8]. In a study done in Germany and Switzerland, a seed rate as high as 100 seeds $\mathrm{m}^{-2}$ was needed to give the highest oil yield [9]. Weiss summarized that seed rates of 30$60 \mathrm{~kg} \mathrm{ha}{ }^{-1}$, dependent on the variety and environment (rainfed or irrigated), are commonly used for large commercial crops [1]. Since seed rates depend on the conditions of the environments, such as moisture availability to the crop during the growing season, the time of seeding, row spacing and method of seeding, it is not surprising that different seed rates are being used for commercial production of safflower in different areas of the world.

Little research on effect of seed rate on safflower production has been conducted in the Mediterranean region. The region is characterized by a dry climate, where limited rainfall occurs in the summer. So there is a need to keep a balance between the amount of vegetative growth with the limited amount of soil moisture to optimize grain yield in rain-fed areas. The objective of the present study was to find the optimal seed rate for rainfed and irrigated safflower cropping systems in a semi-arid Mediterranean region.

\section{MATERIALS AND METHODS}

\section{Site Information}

Field experiments were conducted at the Agricultural Research and Educational Centre $\left(33^{\circ} 56^{\prime} \mathrm{N}, 36^{\circ} 05^{\prime} \mathrm{E}, 995 \mathrm{~m}\right.$ above sea level) of the American University of Beirut in the semi-arid central Bekaa Valley of Lebanon. The long-term annual precipitation of the site is $513 \mathrm{~mm}, 58 \%$ of which 
falls in December, January and February. The long-term mean annual temperature is $13.9^{\circ} \mathrm{C}$. The frost-free period lasts from mid-April to mid-November. The soil type is an alkaline ( $\mathrm{pH}$ 8.0), clayey, Vertic Xerochrept formed from fine textured alluvium derived from limestone.

\section{Treatments and Field Management}

There were four seed rates: $48,24,12$, and $6 \mathrm{~kg} \mathrm{ha}^{-1}$, corresponding to intra-row spacing of $2.5 \mathrm{~cm}, 5 \mathrm{~cm}, 10 \mathrm{~cm}$ and $20 \mathrm{~cm}$, respectively, with a $30 \mathrm{~cm}$ inter-row spacing. This wide range of seed rates was used as no significant differences in grain yield and other agronomic characters, except straw yield, were detected in an earlier experiment using seed rates from 20 to 50 seeds $\mathrm{m}^{-1}$. In 2003/04, one rainfed trial (abbreviated as 2004RF) was carried out. In $2004 / 05$, in addition to the rainfed trial (abbreviated as 2005RF), another trial was conducted under supplemental irrigation (abbreviated as 2005SI) in which a $100 \mathrm{~mm}$ irrigation by sprinklers was given at the bud-initiation stage on April 28, 2005.

The three trials were conducted using a randomized complete block design with four replications. A productive safflower accession, PI 603207, selected from earlier screenings, was used in the study. Seed was treated with a mixture (2:1) of a.i. oxycarboxin and a.i. pirimiphos methyl at a rate of $3 \mathrm{ml} \mathrm{kg}^{-1}$. A small-plot seed drill was used to carry out sowing on 29 November 2003 (emerged 15 December) and 18 December 2004 (emerged 14 January, 2005). Individual plot size was $4 \mathrm{~m} \times 1.8 \mathrm{~m}=7.2 \mathrm{~m}^{2}$ and $3 \mathrm{~m}$ x $1.8 \mathrm{~m}=5.4 \mathrm{~m}^{2}$ for $2003 / 04$ and $2004 / 05$, respectively.

No $\mathrm{P}$ fertilizer was applied since the soil had Olsen-P $>30 \mathrm{mg} \mathrm{kg}^{-1}$. Multi-years studies conducted at the site showed that safflower did not response to $\mathrm{N}$ fertilization after a crop fertilized with $\mathrm{N}$, thus no $\mathrm{N}$ fertilizers were applied to the rainfed trials. The supplementary irrigated trial received $40 \mathrm{~kg} \mathrm{ha}^{-1} \mathrm{~N}$ as ammonium nitrate on 4 March 2005. No other fertilizer was applied as levels of $\mathrm{K}, \mathrm{Mg}, \mathrm{Ca}$, and micronutrients were adequate. Weeds were controlled by hand weeding in spring. An aphidcide (a.i. mevinphos) was sprayed to control aphids near the end of the season.

\section{Sampling and Harvesting}

Plants $\mathrm{m}^{-1}$, stand $\%$, days-to-flowering, plant height, above-ground dry matter, grain yield, and oil percentage in seed were recorded. After winter, number of plants from a random $1 \mathrm{~m}$ row was counted for each plot in the 2004RF and 2005RF trials. Plant stand in percentage was based on visual observation for each plot in the 2004RF and 2005SI trials. Date of flowering was taken when $50 \%$ of the plants had opened flowers. Plant height in $\mathrm{cm}$ was taken near maturity. After maturity, plants from the 4 central rows of the plots were clipped at ground level by hand and weighed. A small-plot thresher was used for threshing. Straw yield was calculated by subtracting grain yield from dry matter yield at maturity. Harvest index was calculated as a percentage of seed over dry matter yield. Oil content was measured only in 2005 , using the NIR technique, and oil yield was calculated by multiplying grain yield by oil content.

\section{Statistical Analysis}

The ANOVA directive of the GenStat package (Version 6) was used to perform the analysis of variance. First, the one-way ANOVA for randomized complete block design was conducted for each trial separately. In the subsequent combined analysis, the default 'general analysis of variance' design option was used. In the combined ANOVA analysis, the fixed-experiment and fixed-treatment model was adopted [10]. The least significant difference was used to compare treatments within a factor only when the F-test of the variable was significant for that factor.

\section{RESULTS}

\section{Weather}

There were large differences in temperature between the two production years (Fig. 1). In 2003/04, monthly average temperatures were close to the long-term means except for March, which was $>2^{\circ} \mathrm{C}$ warmer than the usual. Relative to the long-term average and 2003/04, temperatures in 2004/05 were consistently higher after January, and the difference in February was especially clear $\left(2^{\circ} \mathrm{C}\right.$ warmer $)$.

Precipitation was above the long-term average in 2003/04 $(581 \mathrm{~mm})$ but below the average in $2004 / 05(463 \mathrm{~mm})$. In $2003 / 04$, the season started normally around mid-November, but received $125 \mathrm{~mm}$ more precipitation than the long-term average in January (Fig. 2). Unfortunately, little rainfalls fell after February. For 2004/05, the season also started normally around mid-November, but unexpectedly in the form of snow. The unusual heavy snow delayed sowing. Below normal rainfalls were received in March and April 2005.

\section{Yields and Oil Content}

Seed rate-by-trial interaction was significant $(P<0.05)$ for grain and straw yields. In the 2005SI trial, grain and straw yields were higher under the 24 and $48 \mathrm{~kg} \mathrm{ha}^{-1}$ seed rates than under the two lower seed rates (Table 1). However, there were no significant grain yield differences among seed rates in the 2004RF and 2005RF trials. In the 2004RF trial, straw yield was also not significantly different among seed rates, but the seed rate of $24 \mathrm{~kg} \mathrm{ha}^{-1}$ yielded more straw than the seed rate of $6 \mathrm{~kg} \mathrm{ha}^{-1}$ in the 2005RF trial. Seed rate-by-trial interaction was not significant for harvest index.

The seed rate of $24 \mathrm{~kg} \mathrm{ha}^{-1}$ gave the highest mean grain yield $\left(630 \mathrm{~kg} \mathrm{ha}^{-1}\right)$, which was higher than that under the two lower seed rates (Table 2). The seed rate of $24 \mathrm{~kg} \mathrm{ha}^{-1}$ also gave the highest mean straw yield $\left(2690 \mathrm{~kg} \mathrm{ha}^{-1}\right)$, which was similar to that under $48 \mathrm{~kg} \mathrm{ha}^{-1}$ seed rate, and both were higher than that of the two lower seed rates. Seed rate did not have a significant effect on harvest index. The mean grain and straw yields in the 2004RF trial were lower than that in the 2005SI trial (Table 3). Harvest index in 2004 was lower than both the trials in 2005 .

Seed rate-by-trial interaction was not significant for oil content but was significant for oil yield. Oil yield was higher under the two higher seed rates than under the two lower seed rates in 2005SI, but the oil yield under the seed rate of $24 \mathrm{~kg} \mathrm{ha}^{-1}$ was higher than the other seed rates in 2005RF (Table 1). 


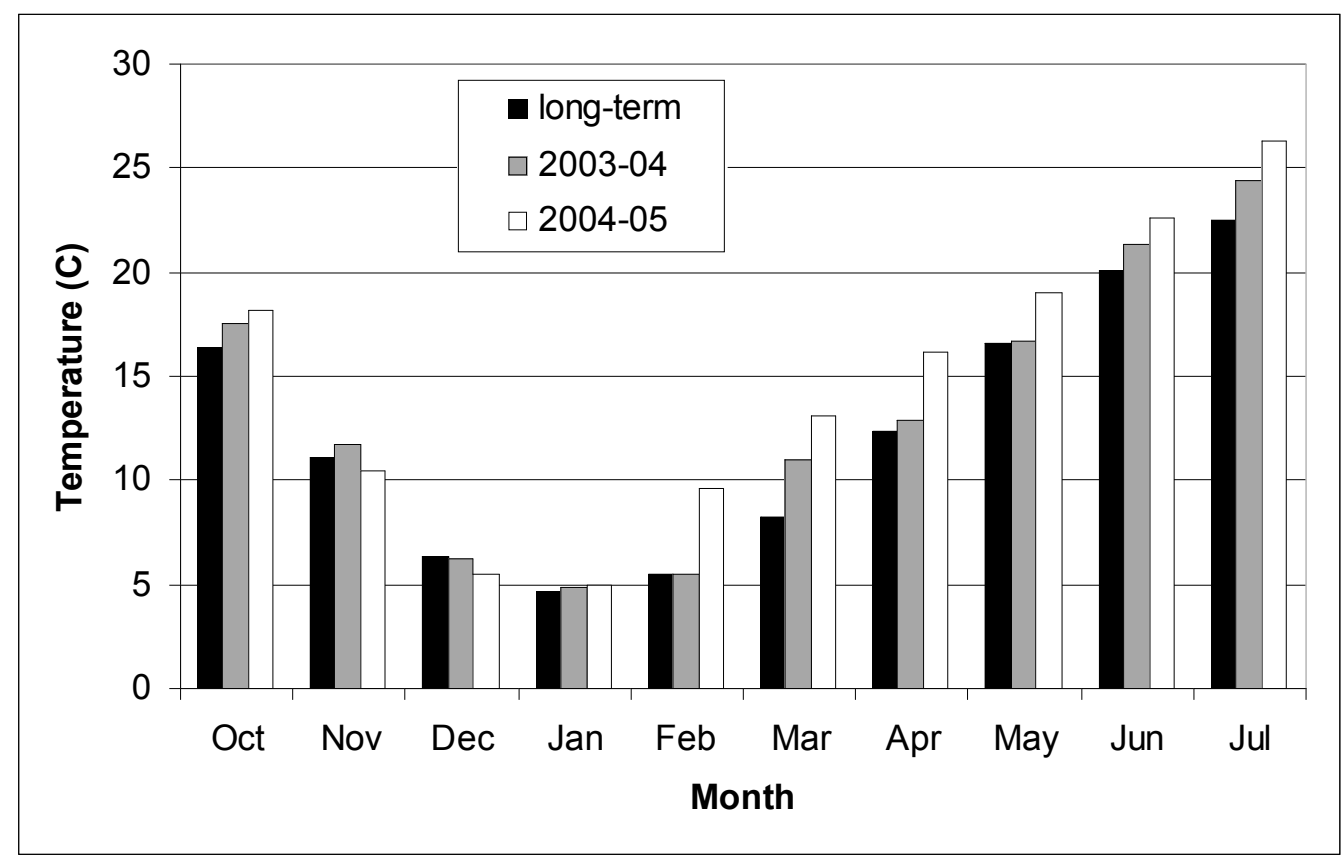

Fig. (1). Monthly average temperatures of the two production years in comparison with the long-term average of 45 years.

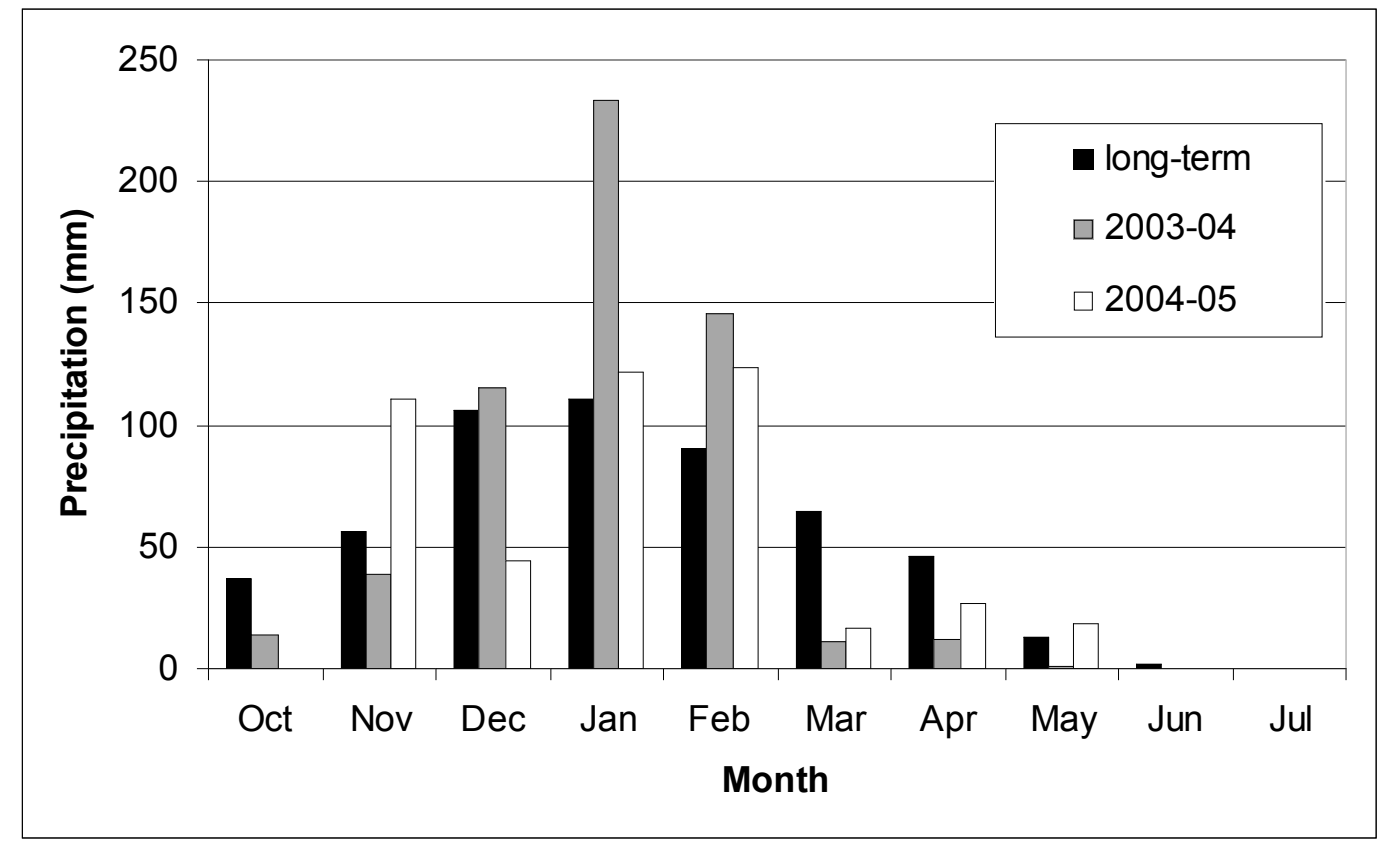

Fig. (2). Monthly precipitation of the two production years in comparison with the long-term average of 45 years.

Mean oil content was not significantly different among the four seed rates (Table 2). Mean oil yield was higher under the $24 \mathrm{~kg}$ ha seed rate than the seed rate of $48 \mathrm{~kg} \mathrm{ha}^{-1}$, which in turn was higher than those produced in the two lowest seed rates. Oil content was also not significantly different between 2005RF and 2005SI (Table 3), but oil yield of 2005SI was much higher than that of 2005RF.

\section{Other Agronomic Traits}

Although seed rate-by-trial interaction was significant for the number of plants $\mathrm{m}^{-2}$, the pattern under the different seed rates was similar in 2004RF and 2005RF except that the range in plant numbers was bigger in the former than in the latter trial (Table 1).
As expected, average numbers of plants $\mathrm{m}^{-2}$ were significantly different among the seed rates, with higher seed rates leading to more plants $\mathrm{m}^{-2}(\mathrm{r}=0.99, \mathrm{P}<0.01$; Table 4). There was more plants $\mathrm{m}^{-2}$ in 2004RF than in 2005RF (Table 5).

For plant stand \%, seed rate-by-trial interaction was also significant (Table 1). In 2005SI, stand \% followed the seed rates proportionally, i.e., a higher seed rate gave a higher stand \%. However, this correspondence was broken in $2004 \mathrm{RF}$ as the two highest seed rates gave similar stand \%. As with plants $\mathrm{m}^{-2}$, stand $\%$ across trials was significantly different among the seed rates (Table 4). Stand \% was higher in 2004RF than in 2005SI (Table 5). 
Table 1. Interaction of Seed Rate and Trial on Different Traits

\begin{tabular}{|cccc|}
\hline $\begin{array}{c}\text { Seeding } \\
\text { Rate } \\
\left.\mathbf{k g ~ h a}^{-1}\right)\end{array}$ & $\mathbf{2 0 0 4}$ & $\begin{array}{c}\text { Trial } \\
\mathbf{2 0 0 5}\end{array}$ & $\mathbf{2 0 0 5}$ \\
& RF & $\mathbf{R F}$ & SI \\
\hline 48 & Grain Yield $\left(\mathrm{kg} \mathrm{ha}^{-1}\right)$ & & \\
24 & 220 & 470 & 890 \\
12 & 300 & 620 & 980 \\
6 & 270 & 500 & 600 \\
LSD $^{\&} 320(201)^{\dagger}$ & 360 & 460 & 510 \\
& & & \\
48 & Straw Yield $\left(\mathrm{kg} \mathrm{ha}^{-1}\right)$ & & \\
24 & 1420 & 1970 & 3680 \\
12 & 1680 & 2160 & 4240 \\
6 & 1510 & 1810 & 1720 \\
\hline \hline & 1810 & 1360 & 1820
\end{tabular}

LSD 1015.8 (697)

$$
\text { Oil Yield }\left(\mathrm{kg} \mathrm{ha}^{-1}\right)
$$

$\begin{array}{cccc}48 & - & 136 & 345 \\ 24 & - & 196 & 338 \\ 12 & - & 152 & 191 \\ 6 & - & 146 & 160\end{array}$

LSD $48(31)$

$\begin{array}{rrc} & \text { Plants (1000) ha } & \\ 48 & 1880 & 1120 \\ 24 & 890 & 590 \\ 12 & 500 & 330 \\ 6 & 260 & 200\end{array}$

LSD $7.9(5.9)$

Plant Stand (\%)

$$
\begin{array}{r}
48 \\
24 \\
12 \\
6
\end{array}
$$

LSD $5.3(5.2)$

\begin{tabular}{|cccc}
\multicolumn{5}{c}{ Days to Flower (from 31 May) } \\
48 & 12 & 11 & 11 \\
24 & 12 & 11 & 11 \\
12 & 10 & 12 & 12 \\
6 & 11 & 13 & 17 \\
LSD $4.9(2.3)$ & & & \\
& Plant Height (cm) & & \\
48 & 41 & 58 & 82 \\
24 & 46 & 63 & 68 \\
12 & 53 & 66 & 70 \\
6 & 63 & 65 & 67 \\
LSD 12.1 (10.6) & & & \\
\hline
\end{tabular}

${ }^{\&}$ at $\mathrm{P}=0.05 ;{ }^{\dagger}$ value within parenthesis is for comparing means within the same trial.
Table 2. Effect of Seed Rate on Yields and Related Characters

\begin{tabular}{|cccccc|}
\hline $\begin{array}{c}\text { Seed } \\
\text { Rate } \\
\left(\mathbf{k g ~ h a}^{-1}\right)\end{array}$ & $\begin{array}{c}\text { Grain } \\
\text { Yield } \\
\left(\mathbf{k g ~ h a}^{-1}\right)\end{array}$ & $\begin{array}{c}\text { Straw } \\
\text { Yield } \\
(\mathbf{k g ~ h a}\end{array}$ & $\begin{array}{c}\text { HI } \\
(\%)\end{array}$ & $\begin{array}{c}\text { Oil } \\
\mathbf{\%}\end{array}$ & $\begin{array}{c}\text { Oil } \\
\text { Yield } \\
\left(\mathbf{k g ~ h a}^{-1}\right)\end{array}$ \\
\hline \hline 48 & 530 & 2360 & 16 & 29 & 240 \\
24 & 630 & 2690 & 19 & 30 & 270 \\
12 & 450 & 1680 & 20 & 31 & 170 \\
6 & 440 & 1660 & 20 & 31 & 150 \\
$\mathrm{LSD}^{\dagger}$ & 115 & 400 & $\mathrm{~ns}$ & $\mathrm{~ns}$ & 22 \\
\hline $\mathrm{P}=0.05$ & & & & &
\end{tabular}

Table 3. Effect of the Trials on Yields and Related

\begin{tabular}{|c|c|c|c|c|c|}
\hline Trial & $\begin{array}{c}\text { Grain } \\
\text { Yield } \\
\left(\mathrm{kg} \mathrm{ha}^{-1}\right)\end{array}$ & $\begin{array}{c}\text { Straw } \\
\text { Yield } \\
\left(\mathrm{kg} \mathrm{ha}^{-1}\right)\end{array}$ & $\begin{array}{l}\text { HI } \\
(\%)\end{array}$ & $\begin{array}{c}\text { Oil } \\
\%\end{array}$ & $\begin{array}{c}\text { Oil } \\
\text { Yield } \\
\left(\mathrm{kg} \mathrm{ha}^{-1}\right)\end{array}$ \\
\hline $2004 \mathrm{RF}$ & 280 & 1610 & 13 & - & - \\
\hline $2005 \mathrm{RF}$ & 510 & 1820 & 22 & 30 & 160 \\
\hline 2005 SI & 750 & 2870 & 22 & 31 & 260 \\
\hline $\mathrm{LSD}^{\dagger}$ & 286 & 878 & 4.8 & ns & 40 \\
\hline
\end{tabular}
Characters

\begin{tabular}{|c|c|c|c|c|}
\hline $\begin{array}{c}\text { Seed } \\
\text { Rate } \\
\left(\mathrm{kg} \mathrm{ha}^{-1}\right)\end{array}$ & $\begin{array}{c}\text { Plants } \\
(1000 \\
\left.\mathrm{ha}^{-1}\right)\end{array}$ & $\begin{array}{c}\text { Plant } \\
\text { Stand } \\
(\%)\end{array}$ & $\begin{array}{l}\text { Days to } \\
\text { Flower } \\
\text { (fr 31/5) }\end{array}$ & $\begin{array}{r}\text { Plant } \\
\text { Height } \\
\text { (cm) }\end{array}$ \\
\hline 48 & 1490 & 95 & 11 & 60 \\
\hline 24 & 730 & 86 & 11 & 59 \\
\hline 12 & 400 & 61 & 11 & 63 \\
\hline 6 & 230 & 43 & 13 & 65 \\
\hline $\operatorname{LSD}(\mathrm{P}=0.05)$ & 43 & 3.6 & 1.3 & $\mathrm{~ns}$ \\
\hline
\end{tabular}

Table 4. Effect of Seed Rate on Other Agronomic Characters

Table 5. Effect of Trials on Other Agronomic Characters

\begin{tabular}{|ccccc|}
\hline Trial & Plants & Plant & $\begin{array}{c}\text { Days to } \\
\text { Flower }\end{array}$ & $\begin{array}{c}\text { Plant } \\
\text { Height } \\
(\mathbf{c m})\end{array}$ \\
\hline \hline 2004 RF & 890 & 90 & 11 & 51 \\
2005 RF & 560 & - & 12 & 63 \\
$2005 \mathrm{SI}$ & - & 53 & 12 & 72 \\
LSD $(\mathrm{P}=0.05)$ & 59 & 2.9 & $\mathrm{~ns}$ & 8.8 \\
\hline
\end{tabular}

Days to flowering also had a significant seed rate-by-trial interaction (Table 1). In 2004RF and 2005RF, seed rates did not affect the days of flowering, but flowering under the lowest seed rate was 5 or 6 days later than the other seed rates in 2005SI. Averaged over trials, flowering was 2 days later under the lowest seed rate than the other three seed rates (Table 4), but there was no significant differences in days to flowering among the three trials (Table 5). 
Cross-over type of seed rate-by-trial interaction occurred in plant height (Table 1). In 2004RF, plants in the highest seed rate were the shortest and they were shorter than those under the seed rates of 12 and $6 \mathrm{~kg}$ ha. However, the reverse was found in 2005SI, in which plants in the highest seed rate were the tallest and they were taller than those in the other three seed rates. No significant difference in plant height among seed rates was found in 2005RF. On average, there was no significant difference between seed rates in plant height (Table 4), but 2005SI gave taller plants than 2005RF, which in turn was taller than plants in 2004RF (Table 5).

\section{DISCUSSIONS}

It is surprising that no difference in grain yield was found in the rainfed trials over years, though the range of seed rates used was increased from 2.5 times difference in the author's previous study to as large as 8 folds difference in the present study. This result supported the observation put forward by [1] that safflower has a big capacity to compensate for planting density producing more secondary and tertiary heads per plant at low density. Besides, under rain-fed, low-rainfall Mediterranean environments, high seed rate will lead to high biomass early in the season and may easily deplete soil moisture before seed formation leading to low grain yield. Thus, it is not surprising that many earlier studies in semi-arid areas using a relatively narrow range of seed rates found that seed rate had a nonsignificant effect on safflower grain yield $[11,12]$.

Unlike in the rainfed trials, the two higher seed rates (24 and $48 \mathrm{~kg} \mathrm{ha}^{-1}$ ) yielded more than the two lower seed rates (6 and 12 $\mathrm{kg} \mathrm{ha}^{-1}$ ) in the trial under supplementary irrigation. This finding was not unexpected. In the USA, for instance, higher seed rates (generally $25 \%$ higher for the same row spacing) are used for irrigated versus rainfed safflower [1]. In an earlier study which was conducted in Lebanon, sown in spring and subjected to full irrigation, increasing population rates from 13 to 53 plants $\mathrm{m}^{-2}$ increased safflower seed, oil and protein yield [13]. Similar results were reported in other crops: optimal seed rate for chickpea in Western Australia has been found to increase with increasing yield potential [14].

Results of this study showed that in semi-arid areas or areas where supplementary irrigation is available, farmers should use the higher seed rate of $24 \mathrm{~kg} \mathrm{ha}^{-1}$, which gave the highest grain yield across the three trials in this study. The author believes that even if supplementary irrigation is not available, the large variation in annual rainfall in semi-arid areas warrants the use of this seed rate $\left(24 \mathrm{~kg} \mathrm{ha}^{-1}\right)$ as it will benefit in years with above average rainfall. However, in rainfed low-rainfall areas, the author believes that farmers should sow with low seed rates at 6 to $12 \mathrm{~kg} \mathrm{ha}^{-1}$. Based on cost, the $6 \mathrm{~kg} \mathrm{ha}^{-1}$ rate is preferable, but the rate of $12 \mathrm{~kg} \mathrm{ha}^{-1}$ may be more acceptable to farmers as it gives a margin against winter kill and other unexpected events.

Oil content of safflower seed is one of the most important factors affecting the success of safflower introduction in any new area. In this study, seed rate had no effect on oil content. Thus, variation in oil yield was mainly caused by differences in grain yield under the different seed rates. Similar findings were reported earlier in safflower $[11,15]$.

\section{CONCLUSIONS}

Safflower has a large capacity to compensate for low plant density. In the Bekaa Valley of Lebanon, the seed rate of $24 \mathrm{~kg}$ $\mathrm{ha}^{-1}$ was found optimal for seed production in autumn-sown safflower grown in semi-arid areas or areas where supplemental irrigation is available.

\section{ACKNOWLEDGEMENTS}

I thank the University Research Board of the American University of Beirut for funding the research, Ms. Diana Abu Eid for assistance in the field and Ms. Karma Bou Azza for technical help in preparing this manuscript.

\section{REFERENCES}

[1] Weiss EA. Oilseed Crops. 2nd ed. Oxford: Blackwell Science 2000.

[2] Knowles PF. Safflower. In: Simmonds NW, Ed. Evolution of crop plants. London: Longman 1976; pp. 31-3.

[3] Hajichristodoulou A. Comparison of oilseed crops with wheat and barley in a dry Mediterranean climate. Exp Agric 1992; 28: 343-9.

[4] Yau SK. Yield, agronomic performance, and economics of safflower in comparison with other rainfed crops in a semi-arid, high-elevation Mediterranean environment. Exp Agric 2004; 40: 453-62.

[5] Kaffha SR, Kearney TE. In: Safflower Production in California. 1998. Available from: http://agric.ucdavis.edu/crops/oilseed/saff8 culture.htm

[6] Herdrich N. Safflower production tips. Cooperative Extension of Washington State University, extension bulletin 1890, 2001.

[7] Mundel HH, Morrison RJ, Entz T, et al. Row spacing and seeding rates to optimize safflower yield on the Canadian prairies. Can $\mathrm{J}$ Plant Sci 1994; 74: 319-21.

[8] Naughtin JC. The influence of agronomic practices on the yield and oil content of safflower (Carthamus tinctorius) in the Wimmera region of Victoria. Aust J Exp Agric Anim Husb 1975; 15: 270-5.

[9] Elfadel E. Effect of nitrogen rate and seed density on safflower (Carthamus tinctorius L.) under low-input farming system. Crop Production Institute, University of Hohenheim: Germany 2007.

[10] McIntosh MS. Analysis of combined experiments. Agron J 1983; 75: 153-5.

[11] Gonzalez JL, Schneiter AA, Riveland NR, Johnson BL. Response of hybrid and open-pollinated safflower to plant population. Agron J 1994; 86: 1070-3.

[12] Marchione V. Effect of plant population and row spacing on the yield and some biometric characters of safflower. Proc. 4th International Safflower Conference, Bari, Italy, 2-7 June 1997.

[13] Nasr HG, Katkhuda N, Tannir L. Effects of $\mathrm{N}$ fertilization and population rate-spacing on safflower yield and other characteristics. Agron J 1978; 70: 683-5.

[14] Jettner RJ, Siddique KHM, Loss SP, French RJ. Optimum plant density of desi chickpea (Cicer arietinum L.) increases with increasing yield potential in south-western Australia. Aust J Agric Res 1999; 50: 1017-25.

[15] Ozel A, Demirbilek T, Gur MT, Copur O. Effects of different sowing date and intrarow spacing on yield and some agronomic traits of safflower (Carthamus tinctorius L.) under Harran Plain's arid conditions. Turk J Agric Forestry 2004: 28: 413-9. 